International Journal of Linguistics, Literature and Translation (IJLLT)

ISSN: 2617-0299 (Online); ISSN: 2708-0099 (Print)

DOI: $10.32996 / \mathrm{ijllt}$

Website: https://al-kindipublisher.com/index.php/ijllt/index

\title{
Difficulties and Countermeasures of Han Nationality Students in Learning Kyrgyz Phonetics and Letters
}

\author{
Caifuding Yishake ${ }^{1 *}$, Mariya Mayituohuo ${ }^{1}$, Aasma Saleem ${ }^{2}$ and Xie Lili ${ }^{2 *}$ \\ ${ }^{1}$ Institute of International Cultural Exchange, Northwest Normal University, Lanzhou 730070, China. \\ ${ }^{2}$ College of Social Development and Public Administration, Northwest Normal University, Lanzhou 730070, China \\ Corresponding Author: Caifuding Yishake, E-mail: caifiding1986621@163.com; Xie Lili, E-mail: xielili81@sina.com
}

\section{ARTICLE INFO}

Received: September 12, 2020

Accepted: October 14, 2020

Volume: 3

Issue: 10

DOI: $10.32996 /$ ijllt.2020.3.10.1

\section{KEYWORDS}

Kyrgyz phoneme, pronunciation, consonants, vowels, solution, Latin letter

\section{ABSTRACT}

Language is important for everyone and plays a vital role in the educational and cultural development of a nation. Learning and teaching of any language is a difficult and technical job in every society. The correct pronunciation is the most basic condition to learn a language. Han students face many difficulties to learn the Kyrgyz language. This study will discuss the problems and possible solutions of Han student's difficulty to learn the Kyrgyz language. When the pronunciation is suffixed with the vowel [b] in the consonant, it is a common problem for Han students to learn the Kyrgyz pronunciation of it. Because some students have confused and mixed the phenomenon of phonetic pronunciation in Chinese Pinyin and Kyrgyz. To understand the Kyrgyz pronunciation and knowing the pronunciation skills is difficult, which is based on the accurately grasping of the pronunciation part to understand that there are two pronunciation variants of certain letters in the Kyrgyz language. Applying imitative, replacement, and other practical and effective methods to repeat the pronunciation and for more accurate practice are the good solution for Han student's problems to learn the Kyrgyz language. The teacher should promptly correct the student's pronunciation errors and at the same time strengthens the student's "three more training" method after class. This study can effectively and universally solve the pronunciation problems of Han students. Moreover, this study will help them to learn Kyrgyz phoneme and letters more easily than other methods.

\section{Introduction}

Language is important for everyone and plays a vital role in the educational and cultural development of a nation. Learning and teaching of any language is a difficult and technical job in every society. It is difficult to learn any foreign language (Zhu \& Liping, 2008). The correct pronunciation is the most basic condition to learn a language. To learn a second language, language transfer is commonly used. Language transfer has two types: 1) positive transfer and 2) negative transfer. Positive transfer, when the first language mode and the target language mode are the same and transfer occurs, then the transfer is positive. Negative transfer, when the first language mode is different from the target language mode and transfer occurs, then the transfer is negative. In the latter case, errors induced by the first language will occur in the second language (Elise, 2015). According to the theory of negative language transfer, when Han students are learning Kyrgyz phonetics and characters then they have certain difficulties in pronunciation because the Chinese phonetics and alphabet system are not completely consistent with the Kyrgyz phonetics and alphabet systems (Akhmatov \& Omuralieva, 1990). To understand the pronunciation variations of certain letters in Kyrgyz, to accurately master the pronunciation skills of phonemes with difficulty in pronunciation, to practice repeated pronunciation through the use of imitation, substitution, and "three more training" practicing method after class. This is an

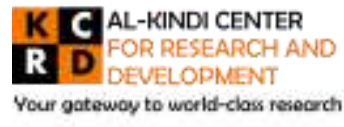

Published by Al-KindiCenter for Research and Development. Copyright (c) the author(s). This is an open access article under CC BY license (https://creativecommons.org/licenses/by/4.0/) 
effective solution to Han student's pronunciation problems. The study aims to provide solutions to Han student's problems regarding learning the Kyrgyz language and to help them for correcting their Kyrgyz language pronunciation. We conducted this research in 2019 at Northwest Normal University, Lanzhou, China. We observed and noted the problems of Han students when they were studying and learning the Kyrgyz language in the Kyrgyz learning classes during the year 2019.

\section{The problem of adding "ы" in the course of Han student's learning Kyrgyz voice and its solution}

When the beginner Han students start to read words that end with a consonant in Kyrgyz, they usually add a vowel "b" at the end. Examples are shown in Table 1.

Table 1. The common pronunciation problems for Han students

\begin{tabular}{cccc}
\hline Wrong Pronunciation & Correct Pronunciation & Chinese Translation & English Translation \\
\hline жолы & жол & 路 & road \\
акы & ак & 白 & white \\
баты & бат & 快 & fast \\
айы & ай & 月亮 & moon \\
топы & топ & 球 & ball \\
\hline
\end{tabular}

\subsection{Theory of second language acquisition}

According to the theory of second language acquisition (SLA), it is generally accepted that the learner's first language (L1) has a great influence on SLA (Elise, 2015). For example, when French people speak English, they have French pronunciation characteristics. As mentioned earlier, when Han students pronounce words, the phenomenon of adding vowels bl also exists in other language learning, which is caused by the internal pronunciation rules of Chinese. If the students of Han nationality only have an increase in the b in learning Kyrgyz, but this phenomenon does not occur in the process of learning other languages, we speculate that this is caused by external factors (Rod-Ellis, 1985). However, studies have shown that when Han students learn foreign languages, they add the vowel bl to the suffixes of words ending in consonants and this has become a common problem. Because, when the Han students learning Chinese initials they didn't pronounce only the initials, but they pronounce the basic form of "initials + b", which is incorrect (Jianxiong, 2009). Therefore, Han students encounter consonants ending in consonants when learning foreign languages (Guanghu et al., 1999). They usually do not pronounce the consonant's sound; but instead, use the usual spelling method of "consonant +ы". Based on this, it can be seen that this is a manifestation of incorrectly applying the pronunciation habits of the mother tongue to learn a foreign language (Kubatalieva et al., 2017).

Therefore, practicing the pronunciation of consonants is also very important for foreign language learning. To avoid and eliminate such problems, the following two methods can be used.

\subsection{Teaching methodology}

First, when the teacher teaches students pronunciation especially when they are learning consonants, they should teach the students to read the original sound of the consonant, not the sound group with vowels. If you add b and similar vowels when teaching consonants, students will mistakenly think that it is a "consonant + b" mode. This also happens when the vowel bl added at the end of the word and the word will pronounce in the same way (Zhenhua, 2017). So the teachers should make sure that they are focusing on the student's proper pronunciation of consonants, words and letters.

\subsection{Monitoring of voice exercises}

Second, teachers should strengthen the monitoring of voice exercises. In the process of phonetic learning, students should practice imitating and recognizing reading under the guidance of teachers. Don't let students practice pronunciation blindly. Sometimes students make the wrong sound, but they don't realize it, which is even more unfavorable for correcting sound. When spelling words that end with a consonant in Kyrgyz, the teacher should keep students in mind that the pronunciation of the consonant is not the "consonant + b" mode of pronunciation, but only the actual pronunciation of the consonant. To be precise, students should understand that the consonant suffix bl the end of a word is wrong.

\section{Han student's difficulty in distinguishing the pronunciation of certain phonemes}

First of all, some beginners have difficulty distinguishing the three sounds of $и, \breve{и}$ and $э$ in Kyrgyz. There are indeed similarities between them: the vowels $э$ and $\boldsymbol{n}$ are both non-labialized vowels in the front of the tongue, that is, the vowels in the front of the tongue; when the vowels $и$ and consonants $\breve{h}$ are pronounced, the tongue position is close to the hard palate with a narrow gap. But these all sounds have significant differences: the sound $\breve{n}$ is a voiced consonant, which is produced by the airflow 
exhaled from the lungs breaking through the barrier formed by the tongue and hard palate, and the vocal cords vibrate; 2) while the sound $n$ is a vowel, the tongue is slightly raised during its pronunciation. High and forward, the airflow is exhaled from the gap between the tongue surface and the hard palate unimpeded.

\subsection{Methods of pronunciation visualization}

The pronunciation practice and method of pronunciation visualization (using the vowel mouth diagram) can help students to distinguish these three voices (Figure 1).

\subsubsection{Accurately master the pronunciation methods and parts of these voices}

The pronunciation of the consonant $\breve{n}$ and the vowel $u$ is very similar, but when pronouncing it, it is necessary to observe whether the airflow is obstructed by the articulator when exhaling. If it is obstructed, it is the consonant $\breve{h}$, if it is not obstructed, it is the vowel $\boldsymbol{n}$. When the pronunciation $\breve{h}$ is pronounced, the gap between the tongue surface and the hard palate is relatively narrower, and the airflow breaks through the obstacles to make sound, while the speech $\boldsymbol{n}$ does not need to break through the obstacles to make a sound. In pronunciation, students can distinguish the vowel $ə$ and the consonant $и$ more accurately. After the students can distinguish the pronunciation $\breve{и}$ and $u$ and $\breve{n}$ and $э$, the difference between the vowel $u$ and $э$ will no longer be a problem. When the teacher shows the above-mentioned tongue vowel diagram to the students, the students can understand the difference between the two vowels according to the teacher's pronunciation guidance. When the vowel $n$ is pronounced, the tongue position is higher and the opening degree is smaller; while the vowel $\ni$ is pronounced lower than $u$, and the opening degree is slightly larger. The most important thing is that beginners should also practice spelling words with these two vowels after class to distinguish the pronunciation of these two sounds.

\subsubsection{Visualize pronunciation}

When beginner students learn phonetics, phonetic theory cannot be explained in the target language, nor can it be explained in the student's mother tongue (the composition of students in the class is complicated) (Akhmatov \& Omuralieva, 1990), so it can only be taught through visual methods. To make students learn pronunciation essentials clearly, these three voices can be displayed through the frontal lip chart (Elise, 2015) (Figure 1).

Figure 1. Mouth shapes to pronounce three different Kyrgyz phonemes

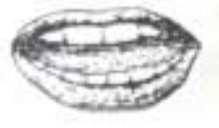

9[e]

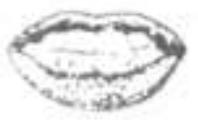

н[i]

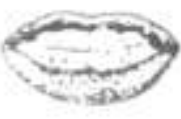

$\mathrm{n}[\mathrm{i}]$

By comparing the mouth shapes (Figure 1), it is not difficult to find that the mouth opening of the phoneme $\ni[$ e] is slightly larger than that of the phoneme $u[i]$. The opening of the mouth when the pronunciation $u[i]$ and the pronunciation $\breve{n}[j]$ are the same, but the tongue position is different. When the vowel $u$ is pronounced, the tongue is higher, and the consonant $\breve{n}[j]$ is lower when it is pronounced. In class, students can bring a small mirror, look at the mouth chart while watching the teacher's demonstration, and then imitate the mirror. Through the visualization of pronunciation, that is, the use of vowel-mouth diagrams, students can more accurately grasp the opening degree of the mouth, whether the lips are rounded, whether the lips are closed, and the scale of teeth exposed. This intuitive and convenient method can help students to understand the pronunciation characteristics of each tone more deeply and make their pronunciation more accurate (Elise, 2015).

\subsection{Beginners problem to distinguish the sounds of ' $\mathrm{H}$ ' and ' $\mathrm{H}$ '}

Secondly, some beginners cannot distinguish the two sounds of $\mathrm{H}$ and $\mathrm{H}_{\text {in }} \mathrm{Kyrgyz}$ (Table 2).

Table 2. Examples of common and easily confused words for Han students to learn the consonants $\mathrm{H}$ and $\mathrm{H}_{4}$

\begin{tabular}{cccc}
\hline Wrong Pronunciation & Correct Pronunciation & Chinese Translation & English Translation \\
\hline жангак & жаңгак & 核桃 & walnut \\
күрөн & күрөң & 褐色 & brown \\
дөнгөлөк & дөңгөлөк & 轮子 & wheel \\
мөнгу & мөңгү & 冰川 & glacier \\
конгуроо & коңгуроо & 铃子 & Suzuko \\
\hline
\end{tabular}


Both $\mathrm{H}$ and $\mathrm{m}_{\text {in }}$ the Kyrgyz phonetic system are voiced nasal consonants, and there is a clear difference between the two phonetics. When the voice $\mathrm{H}$ is pronounced, the tip of the tongue abuts the upper gums, the airflow is exhaled from the nasal cavity, and the vocal cords vibrate. The pronunciation of $\mathrm{H}$ is similar to Chinese $\mathrm{n}$. The pronunciation of $\mathrm{ng}[\mathrm{\eta}]$ in pronunciation. During the pronunciation, airflow is exhaled from the nasal cavity, and the tongue shrinks back, blocking the uvula. The pronunciation organs of these two sounds are shown in the figure below:

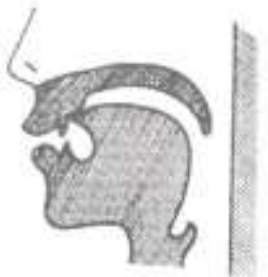

Figure 2. (a) The pronunciation of the Kyrgyz consonant $\mathrm{H}$

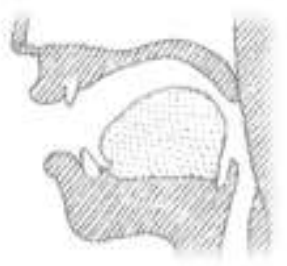

(b) The pronunciation of the Kyrgyz consonant $\mathrm{H}_{1}$

It is not difficult to see and understand from the above picture that the pronunciation parts of these two voices are different. The reason why some Han students cannot distinguish between these two sounds is that they cannot distinguish between the two sounds of $\mathrm{n}$ and $\mathrm{ng}$ in Chinese. Studies have shown that students who can distinguish between $\mathrm{n}$ and $\mathrm{ng}$ in Chinese can also distinguish н and ң $_{1}$ in Kyrgyz, which can also reflect the influence of Chinese phonetic transfer on Kyrgyz phonetics (Zhejun \& Xuemei, 2016).

To help students accurately distinguish the pronunciations $\mathrm{н}$ and $\mathrm{ң}_{\mathbf{1}}$ in Kyrgyz, the following two methods can be used.

(1) The teachers should understand and master the difference between $\mathrm{n}$ and $\mathrm{ng}$ in Chinese, and then teach students in detail the differences in pronunciation parts and ways of these two sounds. At this time, students can use pronunciation visualization methods, that is, teachers can demonstrate to students, and students can also use the pronunciation maps of these two pronunciations to accurately find out their pronunciation parts, and then gradually master the essentials of pronunciation.

(2) The second is speech flow, that is, two sets of words or sound groups (in speech flow) with $\mathrm{H}$ and $\mathrm{H}_{\text {l }}$ letters are selected for comparative spelling training. After class, you also need to seek help from the teacher or students who can pronounce accurately to practice pronunciation repeatedly.

\subsection{Beginners confusion to use ' $p$ '}

Finally, beginners tend to confuse the Kyrgyz consonant $p[r]$ with the Chinese consonant $p\left[p^{\prime}\right]$. Examples are shown in Table 3. Students confuse these two sounds when they pronounce it because they have not fully mastered the alphabets of Kyrgyz, and partly because the two letters are similar in writing, but the sounds represented by the two letters are not the same. The solution to this problem is to keep in mind that the letter in Kyrgyz is a vibrato, while in Chinese it is a bilabial exhalation sound, that is, the two phonetic systems should be understood accurately, but this kind of letter confusion only exists among individual students.

Table 3. Examples of confusing words between Kyrgyz consonant $p[r]$ and Chinese phonetic $p\left[p^{\prime}\right]$

\begin{tabular}{cccc}
\hline Wrong-way of writing & The correct way of writing & Chinese Translation & English Translation \\
\hline кар'а & кара[kara] & 看、黑 & look, black \\
тар' & тар[tar] & 窄 & narrow \\
жар`айт & жарайт[dzarayt] & 可以、行 & ok, ok \\
ор'о & оро[оro] & 卷起来 & roll up \\
төр`ө & төрө[tørø] & 生 & give birth \\
\hline
\end{tabular}

\section{Problems in writing some letters and their solutions}

Kyrgyz is written in the Cyrillic alphabet, so it is not easy to quickly grasp the writing rules of Kyrgyz. Besides, it is important to note that individual letters in the Cyrillic alphabet are easily confused with the letters in the Latin alphabet. For example, when Han students are learning to write the Kyrgyz letter $\mathrm{T}$, it is easy to write the Latin letter $\mathrm{t}$, as shown in Table 4. 
Table 4. Examples of confusing words in Kyrgyz consonant $\mathrm{T}$ and Latin letter $\mathrm{t}$

\begin{tabular}{cccc}
\hline Wrong-way of writing & \multicolumn{1}{c}{ The correct way of writing } & Chinese Translation & English Translation \\
\hline tарак & тарак & 梳子 & comb \\
китеп & китеп & 书 & book \\
кеt & кет & 去 & gо \\
ata & ата & 父亲 & father \\
улуt & улут & 民族 & Nation \\
\hline
\end{tabular}

It is understood that not all students will have the problem of confusion in writing such letters. The reason why there is confusion when writing letters is that students have not fully mastered the writing rules of the Kyrgyz alphabet. At this time, students should be explained in detail to the difference between the writing of the Kyrgyz alphabet and the Latin alphabet. At the same time, the students are required to keep in mind the form of the Kyrgyz alphabet. To be precise, the printed form of the letter $T$ in Kyrgyz is always $\mathrm{T}$, and the form of $\mathrm{t}$ is not written in Kyrgyz, this point should be emphasized to students.

Moreover, some students may have substitutions when writing Kyrgyz letters. For example, write гүл аs түл, жагат аs жатат, сыйлаган аs сыйлатан, and алга аs алта. If the teacher does not pay attention when writing a word with the letter г on the blackboard, students will also make mistakes when writing. In addition to the language ability of second language learners (Han students), the learner's learning attitude, that is, the students do not pay attention to listening in class or remember the wrong form in their minds when they read the wrong way.

To prevent similar mistakes, teachers should write accurately during the writing process, and at the same time make students remember letters with similar writing forms, and students should also pay attention in class (Xiang, 2016). Additionally, for Han students who are new to Kyrgyz, they should only be taught the printed form of the Kyrgyz alphabet (Jalilov, 1996). Because the Kyrgyz alphabet's various writing styles and handwriting styles are not the same. The writing method of some letters in different forms is also a difficult point for students. This will easily cause some phonetic confusion and affect the learning of Kyrgyz phonetics. Therefore, when learning the Kyrgyz alphabet, it is recommended to learn only its printed form. Also, some students could not distinguish the written form of $л$ and $n$ in Kyrgyz, because the two letters are very similar in printed form (Table 5).

Table 5. Examples of confusing words in Kyrgyz consonants $л$ and $п$

\begin{tabular}{cccc}
\hline Wrong-way of writing & The correct way of writing & Chinese Translation & English Translation \\
\hline ала & апа & 妈妈 & mom \\
кала & капа & 生气 & angry \\
жала & жапа & 苦 & bitter \\
тарал & тарап & 方面 & aspect \\
жаллы & жалпы & 综合 & comprehensive \\
\hline
\end{tabular}

It can be seen from the above table that some students regard the letter $n$ as the letter $\pi$, and the pronunciation of the word has changed accordingly. When explaining the alphabet, students should keep in mind the writing and handwriting of the Kyrgyz alphabet to avoid similar mistakes. If students make similar mistakes in spelling, correct them in time. When learning these two letters, you can vividly compare the printed letter $n$ to a door, while the left half of the printed letter of the letter $\pi$ is curved, which can be vividly compared to a lady's high heels. Through a similar analogy method, students can grasp the difference between these two letters in writing.

\section{Conclusion}

It is very important to systematically analyze the difficulties of Han students in learning the Kyrgyz language. Only by mastering Kyrgyz phonetics and letters systematically and normatively can we learn the Kyrgyz language better. Beginner learners will have problems with accentuated $b$, unable to distinguish the pronunciation of $u, \ni$ and $\breve{n}$, difficult to distinguish the pronunciation of

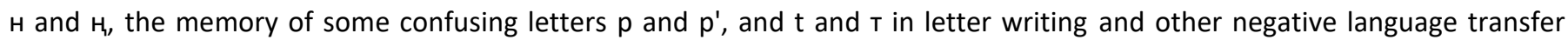
phenomena. From the detailed analysis of the sound quality, pronunciation method and pronunciation part, combined with the actual pronunciation situation, the phonetic system of Kyrgyz and Chinese has a huge difference. Therefore, the sound quality, pronunciation method and pronunciation are involved in the pronunciation of these two voices. There are differences in the use 
of organs at the time of pronunciation. There is no law of vowel harmony in Chinese, but the law of vowel harmony is perfectly preserved in Kyrgyz. In short, the influence of a series of subjective and objective factors such as the first language, environment, language input, learner differences, learner learning methods and classroom teaching will cause Han students to encounter difficulties in learning Kyrgyz voice.

Students try to find some parts of the pronunciation used in the pronunciation process, through the use of similar sounds, find the pronunciation parts and infer the tongue position of these voices, etc. to apply interpretation; use pronunciation visualization (using Vowel mouth patterns), strengthen the monitoring of pronunciation practice, practice pronunciation through methods or means such as speech flow teaching; at the same time pay attention to the spelling of Kyrgyz letters. In the course of teaching, the teacher demonstrates the pronunciation of these voices through precepts and deeds and puts these voices in the vocabulary to teach students. After class, students are required to continuously practice and experience based on theoretical knowledge. When students pronounce, the teacher should point out and correct student's mistakes in time; students should listen carefully when learning Kyrgyz phonetics, listen more, speak more, and write more during the learning process. These methods can fundamentally solve the problems encountered by Han students in learning Kyrgyz. In light of this study, it is suggested that the research should be carried out on a large scale across the country to record more problems of Han students and to find their solutions. Moreover, a database of such problems with possible solutions should be established to provide an effective guideline to Han students or the students who have similar difficulties to learn the Kyrgyz language.

\section{Author's contribution}

$\mathrm{CY}$ conceived the idea and wrote the first draft of the manuscript. $\mathrm{CY}, \mathrm{MM}$ and $\mathrm{AS}$ collected and analyzed the data. $\mathrm{CY}$ and $\mathrm{XL}$ edited and revised the manuscript. MM and AS translated the manuscript into English and revised the language of the manuscript.

\section{References}

[1] Akhmatov, T., \& Omuralieva, S. (1990). Kyrgyz Language Phonetics Vocabulary, Frunze.

[2] Kubatalieva, B., Abykanova, A., \& Asanalieva, M. (2017). Alippe, Bishkek.

[3] Jalilov, A. (1996). Modern Kyrgyz Language, Bishkek.

[4] Rod-Ellis. (1985). Understanding Second Language Acquisition, Oxford University Press, London.

[5] Zhenhua, H. (2017). Kyrgyz Language Course [M], Beijing Central University for Nationalities Press, Beijing.

[6] Jianxiong, T. (2009). Modern Chinese [M], Hebei People's Publishing House, Shijiazhuang.

[7] Xiang, L. (2016). Persian Course One [M], Peking University Press, Beijing.

[8] Zhejun, J., \& Xuemei, P. (2016). A Study on Mother Tongue Transfer in the Acquisition of Korean Vowels by Han Nationality Students. Journal of Yanbian University (Social Science $2^{\text {nd }}$ ed.).

[9] Guanghu, L., Hengzai, L., \& Zhejun, J. (1999). Mechanical Analysis of Korean Monophonic [J], Chinese Korean Language (1 ${ }^{\text {st }}$ ed.), Volume 6.

[10] Elise. (2018). An Introduction to Second Language Acquisition,(translated by Niu Yumei),: The Commercial Press, Beijing.

[11] Borong, H., \& Xudong, L. (2002). Modern Chinese [M] (pp. 62-63),: China Social Sciences Press, Beijing.

[12] Zhu, L., \& Liping, J. (2008). How to Teach Foreigners Chinese [M] (pp. 158-159), Beijing Language and Culture University Press, Beijing. 